Vol. 5 (1996): 235-249.

\title{
Developing scenarios of atmosphere, weather and climate for northern regions
}

\author{
Timothy R. Carter \\ Agricultural Research Centre of Finland, Office address: Finnish Meteorological Institute, \\ Box 503, FIN-00101 Helsinki, Finland
}

\begin{abstract}
Future changes in atmospheric composition and consequent global and regional climate change are of increasing concern to policy makers, planners and the public. However, predictions of these changes are uncertain. In the absence of single, firm predictions, the next best approach is to identify sets of plausible future conditions termed scenarios.

This paper focuses on the development of climate change scenarios for northern high latitude regions. Three methods of scenario development can be identified: use of analogues having conditions similar to those expected in the study region, application of general circulation model results, and composite methods that combine information from different sources. A composite approach has been used to produce scenarios of temperature, precipitation, carbon dioxide and sea-level change for Finland up to 2100, as part of the Finnish Research Programme on Climate Change (SILMU). Tools for applying these scenarios in impact assessment studies, including stochastic weather generators and spatial downscaling techniques, are also examined.

The SILMU scenarios attempt to capture uncertainties both in future emissions of greenhouse gases and aerosols into the atmosphere and in the global climate response to these emissions. Two types of scenario were developed: (i) simple "policy-oriented" scenarios and (ii) detailed "scientific" scenarios. These are compared with new model estimates of future climate and recent observed changes in climate over certain high latitude regions.
\end{abstract}

Key words: climate change, temperature, precipitation, carbon dioxide, sea-level, uncertainty, baseline, Finland

\section{Introduction}

One of the major constraints on agriculture in northern high latitude regions is climate. Crop growth and production is limited by a prolonged and often severe winter and a short growing season. Crops are frequently grown close to their northern limits of potential, where the reliability of production is closely governed by year-toyear variations in the weather. In historical times, periods of benign climate tended to favour the 


\section{AGRICULTURAL AND FOOD SCIENCE IN FINLAND}

Carter, T.R.: Developing scenarios of atmosphere, weather and climate

clearance and colonisation of agricultural land in the high latitude zone, whilst runs of unfavourable weather contributed to crop losses, famine, farm abandonment and depopulation (e.g. Utterström 1955, Parry 1978, Bergthórsson et al. 1988).

Given the sensitivity of agriculture to climate in these regions, the prospect of a future global climatic warming due to anthropogenic causes could be of considerable significance. There is an increasing body of evidence to suggest that this warming could exceed any recorded change since the end of the last glacial period 10,000 years ago (IPCC 1996). In high latitude regions the warming may be greater than the global average. However, there are still large uncertainties surrounding predictions of future changes.

This paper outlines some approaches used to project future climate change in northern high latitude agricultural regions. The geographical scope of the discussion is the circumpolar boreal zone; broadly the region north of about $60^{\circ} \mathrm{N}$ in Europe and northern Russia, and extending south of $50^{\circ} \mathrm{N}$ in parts of North America and eastern Siberia (Hämet-Ahti 1981). Its focus is on scenarios of changes in atmospheric composition and associated changes in regional climate, both of which may have important consequences for agriculture. An example of an approach to develop scenarios for Finland is described in more detail. These scenarios have been prepared for the Finnish Research Programme on Climate Change (SILMU), and have been applied in several SILMU studies reported in this volume to assess possible impacts of climate change on agriculture.

\section{The changing atmosphere and its effect on climate}

During recent decades, measurements of the Earth's atmosphere have indicated rapid increases in concentration of two important types of constituent: (i) the so-called "greenhouse" gases, including carbon dioxide $\left(\mathrm{CO}_{2}\right)$, methane
$\left(\mathrm{CH}_{4}\right)$, nitrous oxide $\left(\mathrm{N}_{2} \mathrm{O}\right)$ and halocarbons, and (ii) atmospheric aerosols, especially sulphur compounds. Increases in all of these are associated with human activities, in particular fossil fuel combustion, intensive agriculture and deforestation.

Rising concentrations of some of these constituents (e.g. $\mathrm{CO}_{2}$, tropospheric ozone $\left(\mathrm{O}_{3}\right)$ and sulphur dioxide $\left(\mathrm{SO}_{2}\right)$ ) can have direct effects on the surface biosphere, including agricultural plants (see, for example, Hakala and Mela 1996, Bowes et al. 1996). Changes in all of them can affect the radiation balance of the Earth, and hence the global climate. Greenhouse gases warm the surface and lower atmosphere by impeding the escape of terrestrial longwave radiation through the atmosphere and re-radiating some to the surface. In contrast, aerosols usually have a cooling effect on the climate both directly, by absorbing incoming solar radiation, and indirectly, through their role in the formation of clouds which reflect solar radiation out to space.

Estimates of the relative effects of these different constituents in perturbing the radiation balance of the global climate system ("radiative forcing") since pre-industrial times are shown in Figure 1. These estimates are based on a comprehensive review of available evidence (IPCC 1996). They are compared in the figure with estimates of the global forcing due to natural changes in solar irradiance since 1850 . Volcanic eruptions are another source of negative forcing, of a similar magnitude as the positive greenhouse gas forcing shown in Figure 1, but effective for only a year or two after a large eruption (IPCC 1996). It should also be noted that the regional effects of changes in atmospheric composition on climate may differ (sometimes in sign) from the global effects.

The best tools available for evaluating the response of global climate to the radiative forcings shown in Figure 1 are numerical climate models. These are based on physical laws, and attempt to simulate the major processes controlling the climate in the atmosphere, oceans and on land. There is a hierarchy of climate models 
Vol. 5 (1996): 235-249.

Fig. 1. Estimates of the global annual mean radiative forcing $\left(\mathrm{Wm}^{-2}\right)$ from 1850 to 1990 for a number of potential climate change mechanisms. Column heights represent mid-range estimates of the forcing, error bars largely represent the spread of published values and the confidence levels given at the base of the diagram are a subjective assessment of the confidence that the actual forcing lies within the error bar. Source: IPCC (1996).

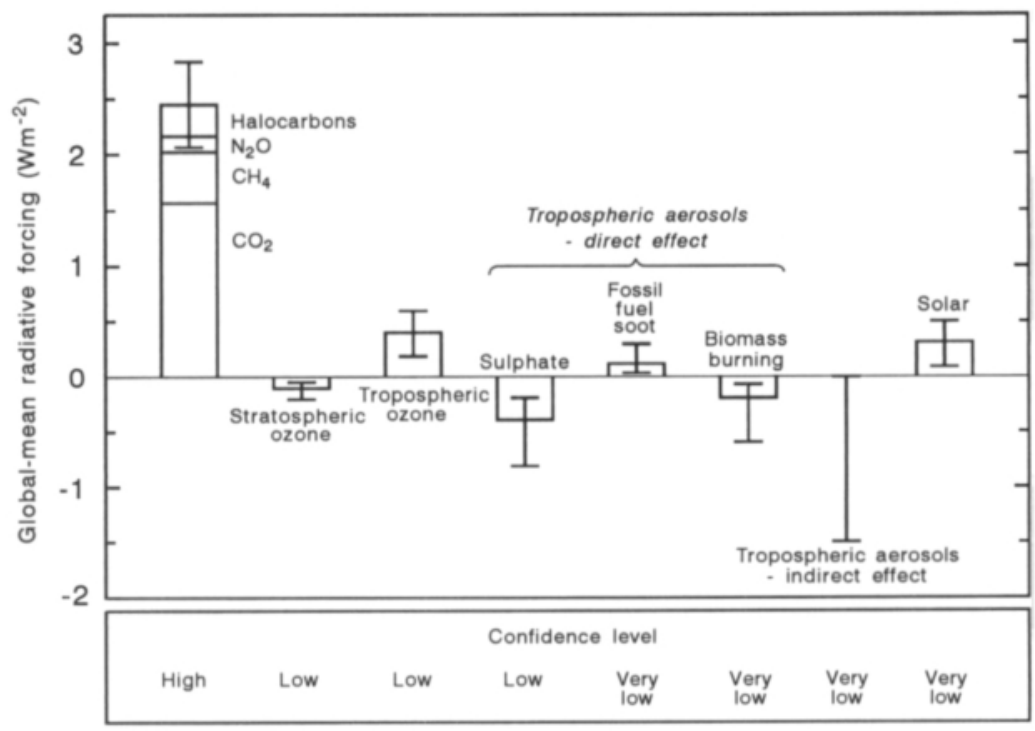

ranging from simple box-models, which have only a few variables, to sophisticated coupled general circulation models (GCMs) of the atmosphere and oceans. They are described further below. However, none of these models are able to capture the full complexities of the climate system, and there are large uncertainties around estimates of regional climate change from GCMs.

\section{The need for scenarios}

Notwithstanding the low confidence in individual model predictions, in order for actions to be taken to prevent or to slow down changes in the atmosphere, policy-makers need to be informed about the possible changes to be expected. Likewise, scientists require projections of these changes so they can examine their likely impacts.

It is also important to recognise that the uncertainties in projections are not due solely to the shortcomings of climate models. Estimation of regional climate change can be thought of as the final step in a sequence of assumptions and uncertainties relating to: (i) future emissions of greenhouse gases and aerosols into the atmosphere, depending on factors such as population growth and economic development; (ii) future atmospheric composition, affected by the quantity, mixing, reactions and residence time of different constituents; (iii) the global climate response to changing atmospheric composition; and (iv) climate changes at the regional and seasonal level. It is at the regional level (where the uncertainty is greatest) that information is most needed in impact assessments.

Since accurate predictions of climate change are not available, an alternative approach is to develop scenarios. These are alternative projections which are meteorologically plausible (i.e. physically, temporally and geographically realistic) and embrace our best available estimates of the uncertainties in projections. The main emphasis in the following sections is on scenarios of future climate, but it should be noted throughout that these scenarios need to be consistent, in time and space, with projections of other related environmental variables such as atmospheric composition and sea-level. 
Carter, T.R.: Developing scenarios of atmosphere, weather and climate

\section{Methods of developing climatic scenarios}

Three main approaches have been used in previous studies to construct scenarios of regional climate change, involving the use of: (i) analogues, (ii) general circulation models, and (iii) compositing. These approaches are described briefly below, with examples mainly drawn from high latitude regions. More extensive reviews of these approaches can be found elsewhere (e.g. Giorgi and Mearns 1991, Pittock 1993).

\section{Analogue scenarios}

Analogue scenarios are constructed by identifying recorded climatic regimes that may serve as analogues for the future climate in a given region. These records can be obtained either from the past (temporal analogues) or from another region at the present (spatial analogues).

\section{Temporal analogues}

Temporal analogues are of two types: those based on past instrumental observations, usually within the last century (e.g. Lough et al. 1983), and those based on proxy data, using palaeoclimatic indicators from the more distant past such as plant or animal remains and sedimentary deposits (e.g. Budyko 1989). Both have been used to identify periods when the global temperature is thought to have been warmer than today. Other features of the climate during these warm periods (e.g. precipitation, air pressure, windspeed), if known, are then combined with the temperature pattern to define the scenario climate. Although the spatial pattern of change sometimes bears similarities with model projections of future climate (see below) a major problem of this technique is that the physical mechanisms giving rise to the warmer climate in the past almost certainly differed from those involved in greenhouse gas induced warming.

\section{Spatial analogues}

A spatial analogue involves the identification of a region today having a climate analogous to that anticipated for the study region in the future. For example, spatial analogues for five northern case study regions are shown in Figure 2 assuming a mean annual warming of about $4^{\circ} \mathrm{C}$. The main drawback of this approach is the frequent lack of correspondence between other non-climatic features of two regions that may affect the local response of agriculture (e.g. daylength, terrain or soils).

Given the many weaknesses of analogue scenarios, their use to represent future climate is not generally recommended (IPCC 1990), though they can contribute useful information for developing composite scenarios (see below).

\section{Scenarios from general circulation models}

While simple numerical models can be used to provide quick estimates of the globally-averaged temperature response to a given forcing mechanism and require little computing power, the geographical pattern of the response can only be estimated with the aid of general circulation models (GCMs). These have been reviewed thoroughly by the Intergovernmental Panel on Climate Change (IPCC - Gates et al. 1992, Kattenberg et al. 1996). GCMs represent the three-dimensional spatial distribution of atmospheric variables such as temperature, pressure, moisture and wind at regular intervals over the entire globe. The computational requirements of such models are immense, and simulations with stateof-the-art GCMs are only possible on supercomputers. Even then, these models are currently incapable of capturing the full complexities of the real climate system. Some of the main weaknesses of these models are (i) a poor representation of cloud processes, (ii) an inability to resolve other sub-grid-scale features such as orographic precipitation and frontal activity, and (iii) a simplified representation of land-atmosphere and ocean-atmosphere interactions. In spite of 


\section{AGRICULTURAL AND FOOD SCIENCE IN FINLAND}

Vol. 5 (1996): 235-249.

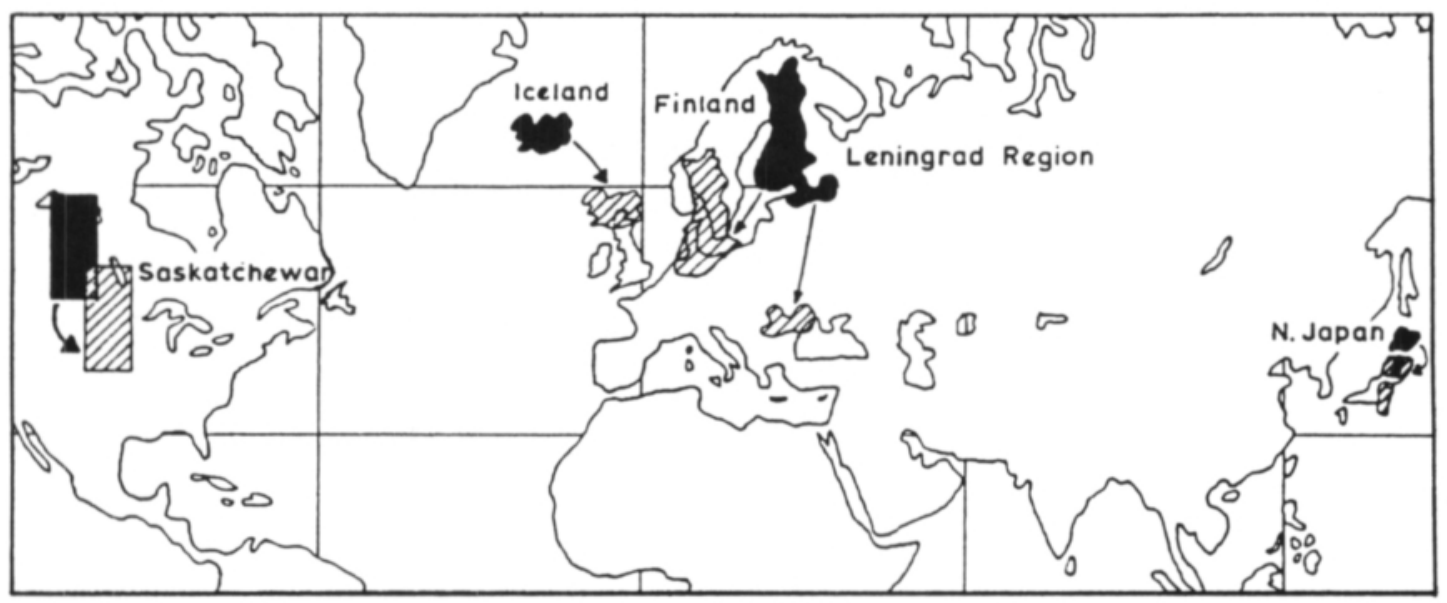

Fig. 2. Spatial analogues for five high latitude regions under the temperature and precipitation changes simulated in the Goddard Institute for Space Studies equilibrium $2 \times \mathrm{CO}_{2}$ model run (Hansen et al. 1983). Modified from Parry and Carter (1988).

recent advances in GCM development, including the coupling of dynamic ocean models to atmospheric models (Gates et al. 1992) and the simultaneous modelling of aerosol and greenhouse gas effects on climate (Kattenberg et al. 1996), regional climate predictions from GCMs remain highly uncertain.

\section{Compositing}

A further method of scenario development combines elements of the above techniques in a compositing approach. This method can range from subjective pooling of regional knowledge on past trends in climate, palaeoclimatic patterns and information from GCMs (e.g. Pittock and Salinger 1982, Jóhannesson et al. 1995) to a more quantitative approach, such as averaging the outputs from different GCMs (e.g. Santer et al. 1990). A quantitative compositing method has also been adopted in developing the scenarios for Finland described in this paper.

\section{Future climate change in Finland: The SILMU scenarios}

This section outlines the climatic scenarios that have been developed for the Finnish Research Programme on Climate Change (SILMU). These scenarios were provided to scientists working in SILMU in the form of a computer program and user's guide (Carter et al. 1995). Only a short description is given here. More details can be found in Carter et al. (1996a).

\section{Model-based estimates}

The scenarios were developed by combining the results from two sets of models: (i) MAGICC, a framework of simple global models and (ii) three coupled ocean-atmosphere GCMs (Figure 3).

\section{Global projections from MAGICC}

The Model for the Assessment of Greenhouse- 


\section{AGRICULTURAL AND FOOD SCIENCE IN FINLAND}

Carter, T.R.: Developing scenarios of atmosphere, weather and climate

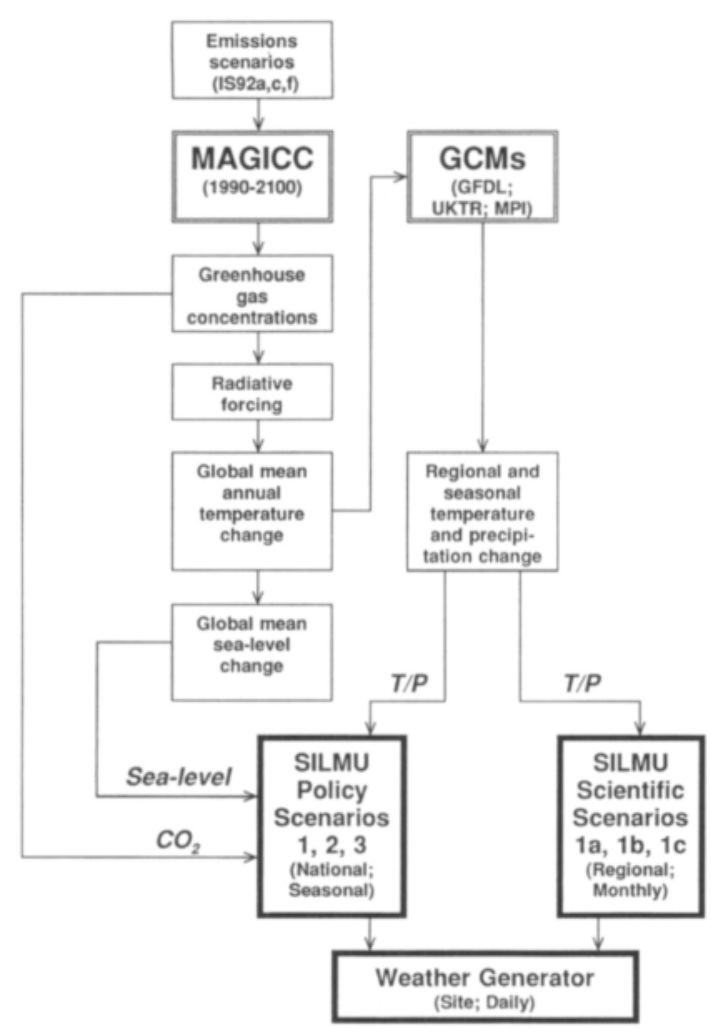

Fig. 3. Method of developing scenarios for SILMU (schematic). Boxes with double lines are models; boxes with single lines are model inputs and outputs; boxes with bold lines are the programs used for generating scenarios. Arrows represent flows of information.

gas Impacts and Climate Change (MAGICC) is a set of linked models for estimating changes in atmospheric composition and radiative forcing under different emissions scenarios and their effect on global mean annual temperature and sea-level (Hulme et al. 1995). It includes all the major greenhouse gases (except tropospheric ozone), fossil fuel derived $\mathrm{SO}_{2}$ emissions and their effects on climate as aerosols, and the effect of halocarbon-induced stratospheric ozone depletion.

MAGICC comprises the following components: (i) a carbon cycle model for computing $\mathrm{CO}_{2}$ concentrations; (ii) simple mass balance models for computing concentrations of methane, $\mathrm{N}_{2} \mathrm{O}$ and halocarbons; (iii) a sulphate aero- sol model for $\mathrm{SO}_{2}$ emissions from fossil sources; (iv) various schemes for converting gas and aerosol concentrations to radiative forcing; (v) an upwelling-diffusion, energy balance model to compute global mean annual temperature and the oceanic thermal expansion component of global mean sea-level rise; and (vi) ice melt models for "small" glaciers and the Greenland and Antarctic ice sheets. These component models, although simple, produce results that are similar to those obtained from more complex, state-of-the-art models. Details about individual model components and full references can be found in the MAGICC Reference Manual (Wigley 1994).

The primary inputs to MAGICC are emissions scenarios at decadal intervals between 1990 and 2100 for the following: fossil $\mathrm{CO}_{2}$, net landuse-change $\mathrm{CO}_{2}, \mathrm{CH}_{4}, \mathrm{~N}_{2} \mathrm{O}, \mathrm{CO}, \mathrm{NO}_{x}$, VOCs, $\mathrm{CFC} 11, \mathrm{CFC} 12, \mathrm{HCFC} 22, \mathrm{HFCl} 34 \mathrm{a}$ and $\mathrm{SO}_{2}$ (Wigley 1994). Emissions scenarios can be selected from a list of published scenarios or can be user-specified. The models calculate the radiative forcing due to emissions over the period 1765-2100, the global mean annual temperature response to a given forcing and the global mean sea-level effect of the temperature change. Model parameter uncertainties are also represented in model outputs.

MAGICC was used in this application to represent two major sources of uncertainty in global estimates of temperature change. The first is the range of possible future emissions, which was based on three IPCC (IS92) emissions scenarios (IPCC 1992). The second is the climate sensitivity, which is a measure of the response of global mean temperature to a given radiative forcing (conventionally a doubling of atmospheric $\mathrm{CO}_{2}$ concentration). The IPCC has specified a range of possible climate sensitivities, based on GCM simulations, of $1.5-4.5^{\circ} \mathrm{C}$, with a best estimate of $2.5^{\circ} \mathrm{C}$ (IPCC 1992).

Three combinations of these sources of uncertainty were selected for SILMU, to represent a central, "best guess" projection and the extreme range:

- Combination 1: Central - central emissions/ central climate sensitivity (IS $92 \mathrm{a} / 2.5^{\circ} \mathrm{C}$ ) 
Vol. 5 (1996): 235-249.

- Combination 2: Low - low emissions/low sensitivity (IS $92 \mathrm{c} / 1.5^{\circ} \mathrm{C}$ )

- Combination 3: High - high emissions/high sensitivity (IS $92 \mathrm{f} / 4.5^{\circ} \mathrm{C}$ ).

MAGICC was run with these three combinations to give a range of $\mathrm{CO}_{2}$ concentrations (based on the emissions scenarios), global mean annual temperature change estimates and sealevel rise estimates for the period 1990-2100. The cooling effect of sulphates was also accounted for in the model runs. The global temperature changes form the basis for the construction of regional climatic scenarios for SILMU (see below). The $\mathrm{CO}_{2}$ and sea-level rise estimates can be applied globally and are used directly in the SILMU scenarios.

\section{Regional projections from GCMs}

Outputs from three general circulation models (GCMs) were used to develop regional scenarios: the Geophysical Fluid Dynamics Laboratory (GFDL) model (Manabe et al. 1991), the United Kingdom Meteorological Office model transient run (UKTR - Murphy 1995) and the Max Planck Institut für Meteorologie (MPI) model (also known as ECHAM-1 - Cubasch et al. 1992). All three models have been used to simulate the transient response of climate to a gradual increase in atmospheric greenhouse gas concentrations for varying periods into the future. The models represent the state of knowledge in the early 1990s. As such, the regional pattern of climate change simulated with these models was for greenhouse gas forcing only, and did not account for sulphate aerosols. An intercomparison of the performance of these models, along with four others, in simulating the present-day regional climate has been reported by Räisänen (1995).

Each GCM produced a different large-scale pattern of climate change for a given forcing, and this varied over time. However, the absolute timing of these changes could not be evaluated directly from the models because future simulations were only started from the present day situation. Since there is a time lag between greenhouse gas forcing and the climate response to this forcing (typically of several decades) due to the thermal inertia of the oceans, the simulated response was unrealistically small in the first few decades of the model runs because they failed to account for the historical build-up of greenhouse gases to which the climate should already have been responding - the so-called "cold start" problem (Hasselmann et al. 1993).

\section{Combining the model outputs}

To overcome the cold start problem, rates of global warming over 1990-2100 were obtained from MAGICC (which does not share the problem) for the scenario combinations described above. Plots of global mean annual temperature change were next constructed for the three GCM simulations. The form of the warming trend given by all three GCMs was close to linear, resembling closely the central estimate curve produced by MAGICC. The modelled years in which the climate warming estimated by the GCMs reached the same level as that obtained from MAGICC for 2020, 2050 and 2100 were extracted from the graphs for each model. By returning to the gridded GCM outputs, the regional changes associated with a given global mean temperature change could now be assigned a date in the future. A period of years of modelled climate around each selected year was used for computing standard climatological statistics.

\section{The SILMU scenarios}

Two sets of scenarios were developed for SILMU based on the above approach: policy-oriented and scientific scenarios.

\section{SILMU policy scenarios}

The SILMU policy-oriented scenarios attempt to capture a range of uncertainties in estimating future climate over Finland. At the same time, they are designed to be simple for scientists to apply and for policy makers to interpret. They depict seasonal changes and are uniform over the 


\section{AGRICULTURAL AND FOOD SCIENCE IN FINLAND}

Carter, T.R.: Developing scenarios of atmosphere, weather and climate

Table 1. Rates of temperature and precipitation change under the SILMU Policy Scenarios, 1990-2100.

\begin{tabular}{lcccccccc}
\hline Period & \multicolumn{3}{c}{ Temperature change $\left({ }^{\circ} \mathrm{C} /\right.$ decade) } & & \multicolumn{3}{c}{ Precipitation change (\%/decade) } \\
\cline { 2 - 3 } \cline { 8 - 9 } & 1 (Central) & 2 (Low) & 3 (High) & & 1 (Central) & 2(Low) & 3 (High) \\
\hline Spring (MAM) & 0.4 & 0.1 & 0.6 & & 0.5 & 0.125 & 0.75 \\
Summer (JJA) & 0.3 & 0.075 & 0.45 & & 1.0 & 0.25 & 1.5 \\
Autumn (SON) & 0.4 & 0.1 & 0.6 & & 1.0 & 0.25 & 1.5 \\
Winter (DJF) & 0.6 & 0.125 & 0.75 & & 2.0 & 0.42 & 2.5 \\
Annual & 0.4 & 0.1 & 0.6 & & 1.0 & 0.25 & 1.5 \\
\hline
\end{tabular}

whole country. Three "policy scenarios" have been developed:

- SILMU Scenario 1: Central

- SILMU Scenario 2: Low

- SILMU Scenario 3: High

The scenarios were developed using the procedures described above. The climate change estimates are GCM grid box values of temperature and precipitation change averaged over the Finnish region and averaged across the three GCMs. They represent regional climate changes over Finland that are consistent with global mean temperature changes obtained from MAGICC for each of the three combinations of global emissions and climate sensitivity shown above. Percentage precipitation changes for Scenarios 2 and 3 are scaled down or up from Scenario 1 estimates in proportion to the respective temperature changes. In this way, upper, lower and central estimates of the rate of temperature and precipitation change up to 2100 are given for Finland (Table 1).

Note that while the estimates of seasonal long-term temperature change are quite similar between individual models, those of precipitation change vary considerably (sometimes in sign). These variations are not expressed in the policy scenarios due to the averaging procedure in the compositing and because of the need to restrict the scenarios to a manageable number. However, they are apparent in the SILMU scientific scenarios (see below).

In view of its importance for examining impacts on agricultural plants, carbon dioxide concentrations computed with MAGICC for 2020,
2050 and 2100 under each SILMU policy scenario are shown in Table 2 alongside the corresponding mean annual temperature and precipitation changes. Also shown are estimates of global sea-level rise. Except for the largest estimates, however, sea-level rise appears likely to be compensated in Finland by the ongoing isostatic uplift of land areas following the last glaciation. While possible changes in the wind regime over the Baltic, which also affects sea-level, complicates this prognosis, future changes in sea-level would appear to pose only a minor threat to agriculture.

Table 2. Global mean carbon dioxide concentration (absolute), mean annual temperature and precipitation change over Finland and global mean sea-level rise relative to 1990 for 2020, 2050 and 2100 under the three SILMU policy scenarios.

Year and attribute SILMU Policy Scenarios

1 (Central) 2 (Low) 3 (High)

2020

$\begin{array}{llll}\mathrm{CO}_{2} \text { concentration }(\mathrm{ppm}) & 425.6 & 408.8 & 433.7\end{array}$

Temperature change $\left({ }^{\circ} \mathrm{C}\right) \quad 1.2 \quad 0.3 \quad 1.8$

Precipitation change (\%) $\quad 3.0 \quad 0.75 \quad 4.5$

$\begin{array}{llll}\text { Sea-level rise }(\mathrm{cm}) & 8.9 & 2.1 & 19.2\end{array}$

2050

$\begin{array}{llll}\mathrm{CO}_{2} \text { concentration }(\mathrm{ppm}) & 523.0 & 456.1 & 554.8\end{array}$

Temperature change $\left({ }^{\circ} \mathrm{C}\right) \quad 2.4 \quad 0.6 \quad 3.6$

Precipitation change (\%) $\quad 6.0 \quad 1.5 \quad 9.0$

$\begin{array}{llll}\text { Sea-level rise }(\mathrm{cm}) & 20.8 & 4.6 & 43.3\end{array}$

2100

$\begin{array}{llll}\mathrm{CO} \text {, concentration }(\mathrm{ppm}) & 733.3 & 484.9 & 848.2\end{array}$

Temperature change $\left({ }^{\circ} \mathrm{C}\right) \quad 4.4 \quad 1.1 \quad 6.6$

Precipitation change (\%) $\quad 11.0 \quad 2.75 \quad 16.5$

$\begin{array}{llll}\text { Sea-level rise }(\mathrm{cm}) & 45.4 & 7.4 & 95.0\end{array}$ 


\section{AGRICULTURAL AND FOOD SCIENCE IN FINLAND}

Vol. 5 (1996): 235-249.

\section{SILMU scientific scenarios}

A second set of SILMU scenarios refer to scenarios that are derived directly from GCM outputs. They provide spatial and temporal variations that the policy scenarios do not. This makes them more technically demanding to apply and to describe, which is why they are labelled "scientific" scenarios, to distinguish them from the simpler policy scenarios. Three scientific scenarios have been developed, based on the three GCMs, and with the same emissions and climate sensitivity assumptions as policy Scenario 1:

\section{- SILMU Scenario 1a: GFDL}

- SILMU Scenario 1b: UKTR

- SILMU Scenario 1c: MPI

The scenarios reflect the pattern of climate change over the Nordic region simulated by each GCM on a monthly basis. They reveal some of the model-to-model differences that are hidden by the compositing technique in the policy scenarios, especially in precipitation projections.
Special routines were included in the computer program supplied to SILMU researchers that linearly interpolate to individual dates and to individual locations in the Nordic region. Alternatively, scenarios can be depicted over a finerscale $1^{\circ}$ by $2^{\circ}$ latitude-longitude grid covering the Baltic region, or a $10 \mathrm{~km}$ grid over Finland. Examples of the regional pattern of mean summer (June-August) temperature change over Finland by 2050 for the three scenarios are shown in Figure 4.

\section{Comparisons with recent GCM simulations}

Since the SILMU scenarios were prepared, more realistic climate change simulations have been conducted that account for both greenhouse gas forcing and the negative regional forcing of sulphate aerosols (Taylor and Penner 1994, Mitchell et al. 1995). The latter of these was with a coupled ocean-atmosphere GCM run beginning (a) Scenario 1a: GFDL

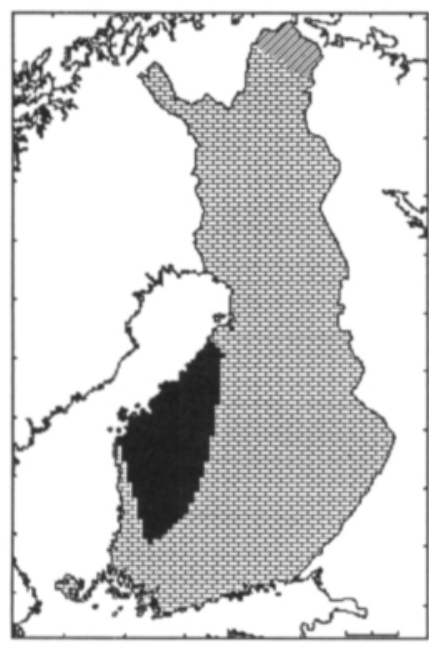

Temperature change $\left({ }^{\circ} \mathrm{C}\right)$ (b) Scenario 1b: UKTR

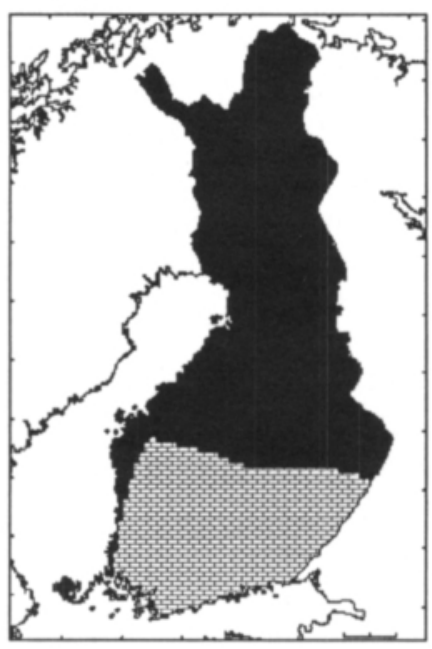

(c) Scenario 1c: MPI

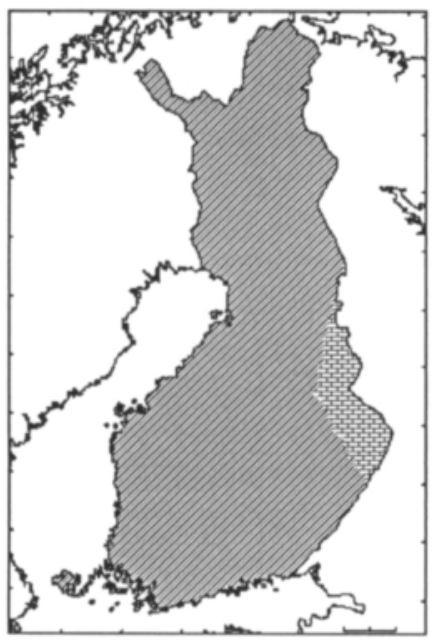

Fig. 4. Mean summer (June - August) temperature change over Finland by 2050 relative to 1990 under the three SILMU scientific scenarios: (a) Scenario 1a (Geophysical Fluid Dynamics Laboratory model), (b) Scenario 1b (United Kingdom Meteorological Office transient model run) and (c) Scenario 1c (Max Planck Institut model). 


\section{AGRICULTURAL AND FOOD SCIENCE IN FINLAND}

Carter, T.R.: Developing scenarios of atmosphere, weather and climate

Table 3. Rates of temperature change in some northern high latitude regions estimated by the Hadley Centre GCM (Mitchell et al. 1995), computed using the SILMU method, (uncertainty range in parentheses), and absolute changes observed between 1951-1980 and 1981-1990 (Folland et al. 1992). Values are taken from maps and are approximate.

\begin{tabular}{|c|c|c|c|c|c|c|c|c|}
\hline $\begin{array}{l}\text { Model or } \\
\text { observations }\end{array}$ & Period & Alaska & $\begin{array}{c}\text { W. } \\
\text { Canada }\end{array}$ & $\begin{array}{c}\text { E. } \\
\text { Canada }\end{array}$ & Iceland & $\begin{array}{l}\text { Fenno- } \\
\text { scandia }\end{array}$ & $\begin{array}{c}\text { N. } \\
\text { Russia }\end{array}$ & $\begin{array}{c}\text { E. } \\
\text { Russia }\end{array}$ \\
\hline $\begin{array}{l}\text { Hadley Centre - } \\
\text { regional aerosols } \\
\left({ }^{\circ} \mathrm{C} / \text { decade }\right)\end{array}$ & Annual & 0.4 & 0.3 & 0.3 & 0.3 & 0.4 & 0.3 & 0.4 \\
\hline $\begin{array}{l}\text { SILMU Method - } \\
\text { global aerosols } \\
\left({ }^{\circ} \mathrm{C} / \text { decade }\right)\end{array}$ & $\begin{array}{r}\text { Annual } \\
\text { Winter } \\
\text { Summer }\end{array}$ & - & $\begin{array}{l}- \\
- \\
-\end{array}$ & $\begin{array}{l}- \\
- \\
-\end{array}$ & $\begin{array}{l}0.15(0.05-0.25) \\
0.15(0.05-0.25) \\
0.15(0.05-0.25)\end{array}$ & $\begin{array}{l}0.4(0.1-0.6) \\
0.5(0.1-0.8) \\
0.3(0.05-0.45)\end{array}$ & $\begin{array}{l}- \\
- \\
-\end{array}$ & $\begin{array}{l}- \\
- \\
-\end{array}$ \\
\hline $\begin{array}{l}\text { Observed: } \\
1981-90 \text { minus } \\
1951-80\end{array}$ & $\begin{array}{r}\text { Annual } \\
\text { Winter } \\
\text { Summer }\end{array}$ & $\begin{array}{r}0.75^{\circ} \mathrm{C} \\
>1.0^{\circ} \mathrm{C} \\
0.25^{\circ} \mathrm{C}\end{array}$ & $\begin{array}{r}0.5^{\circ} \mathrm{C} \\
>1.0^{\circ} \mathrm{C} \\
0.5^{\circ} \mathrm{C}\end{array}$ & $\begin{array}{l}0.25^{\circ} \mathrm{C} \\
0.25^{\circ} \mathrm{C} \\
0.25^{\circ} \mathrm{C}\end{array}$ & $\begin{array}{l}-0.5^{\circ} \mathrm{C} \\
-0.5^{\circ} \mathrm{C} \\
-0.5^{\circ} \mathrm{C}\end{array}$ & $\begin{array}{r}0.25^{\circ} \mathrm{C} \\
0.25^{\circ} \mathrm{C} \\
-0.25^{\circ} \mathrm{C}\end{array}$ & $\begin{array}{l}0.75^{\circ} \mathrm{C} \\
>1.0^{\circ} \mathrm{C} \\
0.25^{\circ} \mathrm{C}\end{array}$ & $\begin{array}{r}0.5^{\circ} \mathrm{C} \\
0.75^{\circ} \mathrm{C} \\
0.25{ }^{\circ} \mathrm{C}\end{array}$ \\
\hline
\end{tabular}

late last century, thus avoiding the cold start problem. The results from this model indicate a rate of increase of global mean annual temperature of about $0.2^{\circ} \mathrm{C}$ per decade for the effects of aerosol and greenhouse gas forcing combined, compared with a rate of $0.3^{\circ} \mathrm{C}$ per decade due to greenhouse warming alone. This reduced rate of warming is much more in accord with the rate observed globally during the present century, enabling the Intergovernmental Panel on Climate Change to declare recently that "the balance of evidence suggests that there is a discernible human influence on global climate" (IPCC 1996).

Changes in mean annual temperature and precipitation for regions in the circumboreal zone have been extracted from mapped outputs of the Hadley Centre model runs (Mitchell et al. 1995) in Table 3. These have been compared to scenarios prepared for Iceland and Fennoscandia using the SILMU method. Note that the SILMU approach also accounts for aerosol forcing, using MAGICC, but this is treated at a global rather than a regional scale. The Hadley Centre results indicate mean rates of warming at high latitudes that are above the global mean. Over Fennoscandia these estimates are consistent with the SILMU scenarios, but over the central North Atlantic region (including Iceland), the SILMU scenario is of a reduced rate of warming, which does not show up in the Hadley Centre simula- tion. The SILMU scenario reflects a weakening of the thermohaline circulation found in the vicinity of Iceland in all three GCMs used to construct the scenario. In fact, the Hadley Centre model, which includes regional aerosol forcing, also shows this effect but its region of influence is shifted to the west of Iceland.

Also shown are observed changes in temperature over the same region between the periods 1951-1980 and 1981-1990 (expressed as absolute changes), providing a tentative comparison with the projected changes. Over continental areas there has been a clear increase in temperature, especially during the winter, while in regions influenced by the North Atlantic recent changes have been smaller or even negative. Thus, the observed pattern of changes, while covering only a short period, does appear to be consistent with the pattern of changes anticipated under greenhouse gas induced climate change.

\section{Applying scenarios in impact assessment}

Several alternative methods exist for applying climate change scenarios in impact studies. Four issues are addressed here: the baseline climate, 
Vol. 5 (1996): 235-249.

adjusting the baseline, downscaling, and the use of a stochastic weather generator.

\section{The baseline climate}

It is important at the outset to define the baseline period against which scenarios are to be compared. Conventionally meteorologists adopt the most recent 30-year climatological "normal" period, currently 1961-1990. This is the period adopted in SILMU. However, in some high latitude regions, including Canada, use of this period as a reference has been resisted, since it is thought to contain a signal of climatic warming (R. Street, personal communication, and see Table 3). Workers in such regions may prefer to adopt an earlier normal period such as 19511980.

\section{Adjusting the baseline climate according to a scenario}

Scenario changes in climate are usually expressed either as differences (temperatures are usually handled this way) or as percentages (commonly applied to precipitation). There are two distinct methods that can be used to apply such changes as adjustments to the baseline climate: the fixed change and transient change approach.

\section{The fixed change approach}

The conventional approach applies a "fixed" scenario change for a given date in the future to all years of the baseline period. The approach is simple and quick to apply. However, it implicitly assumes that the future climate, like the baseline climate, is stationary, whereas in reality, the future climate is likely to be undergoing continual change.

\section{The transient change approach}

A method which accounts for the gradual or "transient" change in climate, adjusts the base- line according to a trend. For example, a linear warming scenario for 2050 could be applied to the 1961-1990 baseline as a trend, with warming by 2036 used to adjust temperatures in 1961, warming by 2037 to adjust 1962 temperatures through to warming by 2065 , which is used to adjust temperatures in 1990. Note that the thirty-year statistical frequency distribution of a scenario climate adjusted according to the transient change approach exhibits greater variability than the corresponding scenario based on the fixed change approach. This may be of some importance when assessing impacts.

\section{Downscaling}

One of the main problems with using information from GCMs is their coarse spatial resolution. Even in the highest resolution GCMs, a single grid box spans an area of more than 50,000 $\mathrm{km}^{2}$. The large scale climate can be greatly modified within an area of this size, by factors such as terrain, vegetation cover or water surfaces. Simple interpolation from grid box scale to local scale, which was used in the SILMU scenarios, neglects these sub-grid-scale features which are not resolved by GCMs. Local variations in climate can, of course, have large effects on agricultural productivity or water supply.

Two alternative approaches have been developed for downscaling from GCM to local scale. The first approach involves the establishment of statistical relationships between large-scale climate and sub-grid-scale climate using past observations (e.g. Wigley et al. 1990, Karl et al. 1990, Bardossy and Plate 1992). The approach assumes that the statistical relationships between these two scales remain unchanged under a future climate.

The second downscaling approach involves the use of limited area high resolution numerical models. These are physically-based models that can be run at sub-continental scale at a resolution of some $50 \times 50 \mathrm{~km}$. They can be linked to GCMs using various nesting techniques, whereby the GCM provides information on large 
Carter, T.R.: Developing scenarios of atmosphere, weather and climate

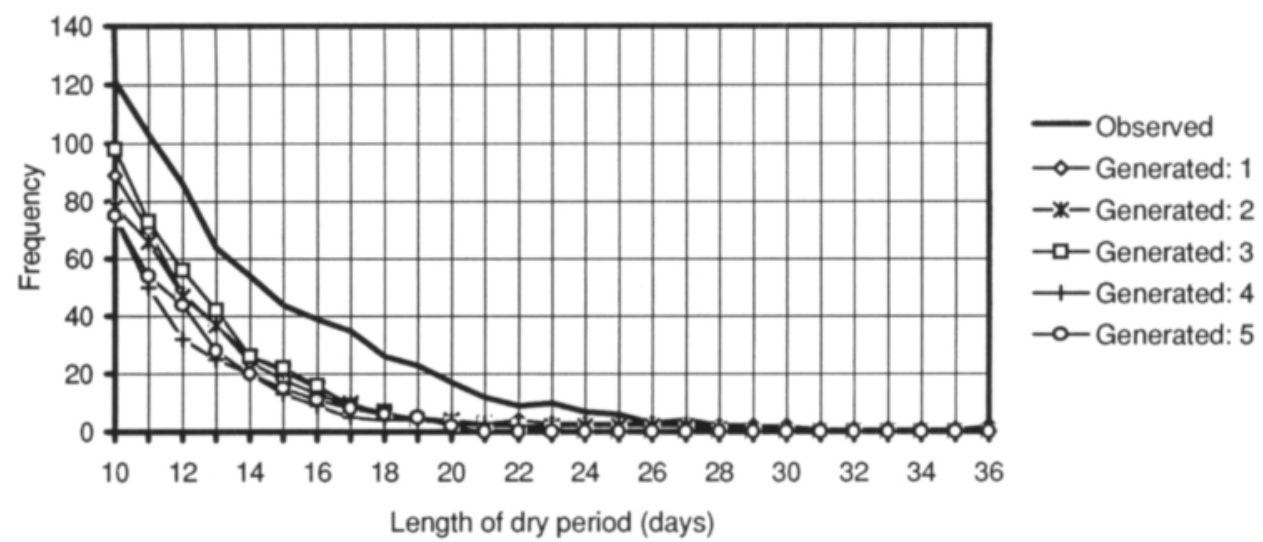

Fig. 5. Frequency distribution of length of dry spells (precipitation $\leq 0.1 \mathrm{~mm}$ ) at Jokioinen, southern Finland, observed (1961-1990) and for five 30-year simulations with the CLIGEN weather generator.

scale flows to the limited area model, which is then run at higher resolution. Early results from such model runs, including high latitude regions of Europe and North America, are now available for impact assessment (e.g. Giorgi et al. 1992, Jones et al. 1995).

\section{Use of stochastic weather generators}

Many impact assessments require detailed climatological data on a daily time step as input to simulation models. Crop growth models are typical examples in agriculture. Daily data are seldom available as outputs from GCMs, and in any case they are not readily applicable in impact studies. An alternative is to use stochastic weather generators. These consist of sets of parameters describing statistical properties of climatic variables observed historically at individual locations. They can be used to generate time series of unlimited length having similar statistical properties to those observed. The parameters of a generator can also be adjusted according to scenarios of future climate. This offers a very flexible tool for conducting sensitivity testing of models, where changes in both the mean and variability of climate can be readily simu- lated (Wilks 1992, Semenov and Porter 1995).

A stochastic weather generator for Finland, CLIGEN, has been developed for SILMU (Posch 1994) and provided to researchers in conjunction with the climatic scenarios (Carter et al. 1995). CLIGEN first simulates time series of precipitation, which is the independent variable in the procedure. Daily temperatures and cloudiness values are then correlated with the occurrence of wet and dry days, based on the method of Richardson and Wright (1984). Time series can be generated for any location in Finland, by interpolating the parameters of the generator from adjacent weather stations.

CLIGEN has been applied over a $10 \mathrm{~km}$ grid across Finland, to estimate effects of SILMU scenario climates on potato late blight (Carter et al. 1996b). One drawback of the generator revealed in that study is a tendency to underestimate the frequency and duration of persistent events like drought and warm or cold spells. It is these episodes that often result in the greatest impacts on agriculture. Figure 5 compares the observed and generated frequencies of dry spells $(\leq 0.1 \mathrm{~mm})$ at Jokioinen. CLIGEN significantly underestimates the frequency of dry spells of 10 days or longer. Further work is required on the generator to correct this problem. 


\section{AGRICULTURAL AND FOOD SCIENCE IN FINLAND}

Vol. 5 (1996): 235-249.

\section{Conclusions}

This paper has presented some estimates of possible environmental changes in northern agricultural regions. Carbon dioxide concentrations in the atmosphere are expected to continue to rise globally, with probable beneficial effects for agricultural crops. Sea-level rise as a consequence of global warming may be of minor significance for agriculture in most regions, since many high latitude land areas are still recovering following deglaciation. Overall, warming at these latitudes (with the possible exception of the North Atlantic region) is anticipated to be larger than the global average. Wintertime precipitation is expected to increase, while the amount and even the sign of precipitation change during the growing season are very uncertain. The warming alone, however, could transform the potential for agricultural production in some areas. As was illustrated in Figure 2, the climate of the late 21 st century in a marginal agricultural region such as southern Finland might resemble that today in Denmark or northern Germany. Inspection of present-day crop production statistics in Denmark reveals levels of yield twice or even three times those found in Finland today. While Denmark may not be a perfect analogue of a future Finland (for example, there are differences in soils, farm size and structure), a substantial portion of this disparity in production potential is climatically induced.

The large uncertainties attached to scenarios of future regional climate are exemplified by the SILMU scenarios. While there is some scope for improving model predictions, using higher resolution models which accurately account for the most important processes in the climate system, these advances are likely to be gradual and piecemeal. Moreover, rapid improvements in the projections of future population growth, regional economic activity, greenhouse gas emissions and atmospheric composition seem unlikely. Thus, although opportunities do exist to narrow the range of scenario uncertainty, it still seems probable that scenarios will continue to play an important role in policy-making and assessment for some time to come.

Acknowledgements. I am grateful to Heikki Tuomenvirta of the Finnish Meteorological Institute, Helsinki, who assisted in developing the SILMU scenarios and to Dr. Maximilian Posch of the National Institute of Public Health and Environmental Protection, Bilthoven, The Netherlands, who developed the stochastic weather generator, CLIGEN. Special thanks are also due to Dr. David Viner and colleagues in the Climate Impacts LINK Project, University of East Anglia, Norwich, UK for supplying GCM information and to Professor Tom Wigley of the University Corporation for Atmospheric Research, Boulder, CO, USA for providing a version of MAGICC. This work was funded by the Finnish Research Programme on Climate Change (SILMU).

\section{References}

Bardossy, A. \& Plate, E.J. 1992. Space-time model for daily rainfall using atmospheric circulation patterns. Water Resources Research 28: 1247-1259.

Bergthórsson, P., Björnsson, H., Dý rmundsson, Ó., Gudmundsson, B., Helgadóttir, Á. \& Jónmundsson, J.V. 1988. The effects of climatic variations on agriculture in Iceland. In: Parry, M.L. et al. (eds.). The impact of climatic variations on agriculture. Volume 1. Assessments in cool temperate and cold regions, Kluwer, Dordrecht, The Netherlands. p. 381-509.

Budyko, M.I. 1989. Empirical estimates of imminent climatic changes. Soviet Meteorology and Hydrology 10 : 1-8.

Carter, T., Posch, M. \& Tuomenvirta, H. 1995. SILMUSCEN and CLIGEN user's guide: Guidelines for the con- struction of climatic scenarios and use of a stochastic weather generator in the Finnish Research Programme on Climate Change (SILMU). Publications of the Academy of Finland 5/95, Helsinki. 60 p. plus diskette.

-, Posch, M. \& Tuomenvirta, H. 1996a. The SILMU scenarios: specifying Finland's future climate for use in impact assessment. Geophysica 32: (in press).

- , Saarikko, R. A. \& Niemi, K. J. 1996b. Assessing the risks and uncertainties of regional crop potential under a changing climate in Finland. Agricultural and Food Science in Finland 5: 329-350 (this issue).

Cubasch, U., Hasselmann, K., Höck, H., Maier-Reimer, E., Mikolajewicz, U., Santer, B.D. \& Sausen, R. 1992. Time-dependent greenhouse warming computations with a coupled ocean-atmosphere model. Climate Dynamics 
Carter, T.R.: Developing scenarios of atmosphere, weather and climate

\section{7: $55-69$.}

Folland, C.K., Karl, T.R., Nicholls, N., Nyenzi, B.S., Parker, D.E. \& Vinnikov, K. Ya. 1992. Observed climate variability and change. In: Houghton, J.T. et al. (eds.). Climate change 1992: The supplementary report to the IPCC scientific assessment. Cambridge University Press. p. 135-170.

Gates, W.L., Mitchell, J.F.B., Boer, G.J., Cubasch, U. \& Meleshko, V.P. 1992. Climate modelling, climate prediction and model validation. In: Houghton, J.T. et al. (eds.). Climate change 1992: The supplementary report to the IPCC scientific assessment. Cambridge University Press. p. 97-134.

Giorgi, F. \& Mearns, L.O. 1991. Approaches to the simulation of regional climate change: a review. Reviews of Geophysics 29: 191-216.

-, Marinucci, M.R. \& Visconti, G. 1992. A $2 \times \mathrm{CO}_{2}$ climate change scenario over Europe generated using a limited area model nested in a general circulation model. 2. Climate change scenario. Journal of Geophysical Research 97(D9): 10011-10028.

Hämet-Ahti, L. 1981. The boreal zone and its subdivision. Fennia 159: 69-75.

Hansen, J., Russell, G., Rind, D., Stone, P., Lacis, A., Lebedeff, S., Ruedy, R. \& Travis, L. 1983. Efficient three-dimensional global models for climate studies: models I and II. Monthly Weather Review 111: 609-662. Hasselmann, K., Sausen, R., Maier-Reimer, E. \& Voss, R. 1993. On the cold start problem in transient simulations with coupled atmosphere-ocean models. Climate Dynamics 9: 53-61.

IPCC 1990. Climate change: The IPCC scientific assessment. Report of Working Group I of the Intergovernmental Panel on Climate Change (Houghton, J.T. et al. eds.). Cambridge University Press, Cambridge, UK. 365 p.

- 1992. Climate change 1992. The supplementary report to the IPCC scientific assessment (Houghton, J.T. et al. eds.). Cambridge University Press, Cambridge, UK. $200 \mathrm{p}$.

- 1996. Climate change 1995. The science of climate change. Contribution of Working Group I to the Second Assessment Report of the Intergovernmental Panel on Climate Change (Houghton, J.T. et al. eds.). Cambridge University Press, Cambridge, UK. 572 p.

Jóhannesson, T., Jónsson, T., Källén, E. \& Kaas, E. 1995. Climate change scenarios for the Nordic countries. Climate Research 5: 181-195.

Jones, R.G., Murphy, J.M. \& Noguer, M. 1995. Simulation of climate change over Europe using a nested regional-climate model. I: Assessment of control climate, including sensitivity to location of lateral boundaries. Quarterly Journal of the Royal Meteorological Society 121: 1413-1449.

Karl, T.R., Wang, W.-C., Schlesinger, M.E., Knight, R.W. \& Portman, D. 1990. A method of relating general circulation model simulated climate to the observed local climate. Part I: Seasonal statistics. Journal of Climate 3: 1053-1079.

Kattenberg, A., Giorgi, F., GrassI, H., MeehI, G.A., Mitchell, J.F.B., Stouffer, R.J., Tokioka, T., Weaver, AJ. \& Wigley, T.M.L. 1996. Climate models - projections of future climate. In: Houghton, J.T. et al. (eds.). Climate change 1995. The science of climate change. Cambridge University Press, Cambridge, UK. p. 285-357.
Lough, J.M., Wigley, T.M.L. \& Palutikof, J.P. 1983. Climate and climate impact scenarios for Europe in a warmer world. Journal of Climate and Applied Meteorology 22 1673-1684.

Manabe, S., Stouffer, R.J., Spelman, M.J. \& Bryan, K. 1991. Transient responses of a coupled ocean-atmosphere model to gradual changes of atmospheric $\mathrm{CO}_{2}$. Part I: Annual mean response. Journal of Climate 4: 785-818 Mitchell, J.F.B., Johns, T.C., Gregory, J.M. \& Tett, S.F.B. 1995. Climate response to increasing levels of greenhouse gases and sulphate aerosols. Nature 376 501-504

Murphy, J.M. 1995. Transient response of the Hadley Centre coupled ocean-atmosphere model to increasing carbon dioxide. Part I. Control climate and flux correction. Journal of Climate 8: 36-56.

Parry, M.L. 1978. Climatic change, agriculture and settlement. Dawson, Folkestone. 214 p.

— \& Carter, T.R. 1988. The assessment of effects of climatic variations on agriculture: aims, methods and summary of results. In: Parry, M.L. et al. (eds.). The impact of climatic variations on agriculture. Volume 1. Assessments in cool temperate and cold regions, Kluwer, Dordrecht, The Netherlands. p. 11-95.

Pittock, A.B. 1993. Climate scenario development. In: Jakeman, A.J. et al. (eds.). Modelling change in environmental systems. John Wiley, Chichester. p. 481-503.

— \& Salinger, M.J. 1982. Toward regional scenarios for a $\mathrm{CO}_{2}$-warmed Earth. Climatic Change 4: 23-40.

Posch, M. 1994. Development of a weather generator for Finland II. In: Kanninen, M. and Heikinheimo, P. (eds.). The Finnish Research Programme on Climate Change. Second progress report. Publications of the Academy of Finland 1/94, Helsinki. p. 323-328.

Räisänen, J. 1995. A comparison of the results of seven GCM experiments in northern Europe. Geophysica 30 : 3-30.

Richardson, C.W. \& Wright, D.A. 1984. WGEN: A model for generating daily weather variables. U.S. Department of Agriculture, Agricultural Research Service, ARS8. $83 \mathrm{p}$

Santer, B.D., Wigley, T.M.L., Schlesinger, M.E. \& Mitchell, J.F.B. 1990. Developing climate scenarios from equilibrium GCM results. Report No. 47, Max-Planck-Institut für Meteorologie, Hamburg. 29 p.

Semenov, M.A. \& Porter, J.R. 1995. Climatic variability and the modelling of crop yields. Agricultural and Forest Meteorology 73: 265-283.

Taylor, K.E. \& Penner, J.E. 1994. Response of the climate system to atmospheric aerosols and greenhouse gases. Nature 369: 734-737.

Utterström, G. 1955. Climatic fluctuations and population problems in early modern history. Scandinavian Economic History Review 3: 3-47.

Wigley, T.M.L. 1994. MAGICC user's guide and scientific reference manual. Climatic Research Unit, University of East Anglia, Norwich. 23 p.

-, Jones, P.D., Briffa, K.R. \& Smith, G. 1990. Obtaining sub-grid-scale information from coarse-resolution general circulation model output. Journal of Geophysical Research 95(D2): 1943-1953.

Wilks, D.S. 1992. Adapting stochastic weather generation algorithms for climate change studies. Climatic Change 22: 67-84. 


\title{
AGRICULTURAL AND FOOD SCIENCE IN FINLAND
}

Vol. 5 (1996): 235-249.

\section{SELOSTUS}

\section{Ilmakehä-, sää- ja ilmastoskenaarioiden kehittäminen pohjoisille alueille}

\author{
Timothy R. Carter \\ Maatalouden tutkimuskeskus
}

Tulevat ilmakehän koostumusmuutokset ja niitä seuraavat maailmanlaajuiset ja alueelliset ilmastonmuutokset huolestuttavat enenevästi poliittisia päätöksentekijöitä, suunnittelijoita ja yhteiskuntaa. Muutosennusteet ovat kuitenkin epävarmoja. Koska luotettavaa ennustetta ei ole, paras lähestymistapa on identifioida joukko mahdollisia tulevaisuuden kehitysnäkymiä ts. skenaarioita.

Tämä artikkeli käsittelee ilmastoskenaarioiden kehittämistä korkeiden pohjoisten leveysasteiden alueille. Skenaarioiden laatimisessa voidaan erottaa kolme eri menetelmää: etsitään analogioita, jotka muistuttavat tulevia tutkimusalueen oloja, käytetään ilmastomallien tuloksia tai yhdistetään useiden menetelmien tuloksia. Suomalaisen ilmakehänmuutosten tutkimusohjelmassa SILMUssa käytettiin yhdistelmämenetelmää laadittaessa vuoteen 2100 ulottuvia skenaarioita lämpötilan, sademäärän, ilman hiilidioksi- dipitoisuuden ja merenpinnan korkeuden muutoksista Suomen alueella. Artikkelissa käsitellään lisäksi eri keinoja käyttää skenaarioita ilmastonmuutoksen vaikutuksia selvittävissä tutkimuksissa. Tällaisiin keinoihin lukeutuvat stokastiset säägeneraattorit ja tilastolliset menetelmät, joilla paikalliset olot liitetään ilmastomallien suuren mittakaavan virtauksiin.

SILMU-skenaarioilla pyritään kuvaamaan epävarmuutta, joka johtuu sekä tulevista kasvihuonekaasujen ja aerosolien päästöistä että maapallon ilmaston vasteesta näihin päästöihin. Skenaarioita laadittiin kahta eri tyyppiä: (i) yksinkertaisia perusskenaarioita ja (ii) yksityiskohtaisia tieteellisiä skenaarioita. Skenaarioita verrataan uusimpiin tulevaisuuden ilmastosta tehtyihin malliarvioihin sekä viimeaikaisiin tietyillä korkeiden leveysasteiden alueilla havaittuihin ilmastonmuutoksiin. 